Institute for Research on Poverty

Discussion Paper no. 1122-97

\title{
Customer Discrimination and Employment Outcomes for Minority Workers
}

\author{
Harry J. Holzer \\ Michigan State University \\ E-mail address: holzer@pilot.msu.edu \\ Keith R. Ihlanfeldt \\ Georgia State University
}

February 1997

We thank John Bound, Carl Davidson, Julie Hotchkiss, David Neumark, David Sjoquist, Paula Stephan, and seminar participants at Michigan State University and Western Michigan University for helpful remarks. We also thank the Rockefeller Foundation for financial support.

IRP publications (discussion papers, special reports, and the newsletter Focus) are now available electronically. The IRP Web Site can be accessed at the following address: http://www.ssc.wisc.edu/irp/ 


\begin{abstract}
In this paper we investigate the effects of consumer discrimination on the employment and earnings of minorities, particularly blacks. We do so using data from a new survey of employers in four large metropolitan areas in the United States. Our results show that the racial composition of an establishment's customers has sizable effects on the race of who gets hired, particularly in jobs that involve direct contact with customers. Although we find evidence of customer discrimination in both predominantly white and black establishments, the net effect of such discrimination appears to be some reduction in overall labor demand and wages for blacks. Evidence is also presented which suggests that the role of customer discrimination may be growing more important over time.
\end{abstract}




\section{Customer Discrimination and Employment Outcomes for Minority Workers}

\section{INTRODUCTION}

Empirical studies generally show that, even after controlling for individual productivity characteristics such as education and experience, blacks have lower levels of employment and earnings than whites. The residual earnings gap between races is commonly attributed to labor market discrimination. ${ }^{1}$

Becker (1971) has identified three possible sources of this discrimination: the prejudice of employers, workers, and consumers. In his model, employer and coworker discrimination will not persist over time in competitive labor markets; some economists (e.g., Nardinelli and Simon 1990) therefore conclude that any labor market discrimination that does persist most likely results from consumer prejudice.

In addition to its possible importance in explaining the residual gaps in employment and earnings between blacks and whites, the possible presence of consumer discrimination in the labor market is of interest for at least two related reasons. First, there is considerable evidence that blacks have been disadvantaged by job suburbanization (for a review of this evidence, see Holzer 1991; Ihlanfeldt 1992; or Kain 1992). However, the reasons for this remain somewhat speculative. Kain (1968) has suggested that consumer discrimination may account for the failure of inner-city blacks to follow jobs to the suburbs. ${ }^{2}$

${ }^{1}$ Neal and Johnson (1996), among others, find that much of the racial gap in hourly earnings disappears when they control for differences in Armed Forces Qualifying Test (AFQT) scores. But Rodgers and Spriggs (1996) and Cawley et al. (1996) show that different components of the AFQT are rewarded among whites quite differently than among blacks, raising questions about whether such returns are really race-neutral measures of skill. Also, a much smaller part of the racial difference in employment rates than wage rates is eliminated by this control.

${ }^{2}$ Evidence that employer discrimination is greater in the suburbs than in the central city is provided by Holzer (1996b). He shows that, for blacks, the ratio of new hires to job applicants is significantly lower in suburban than central-city establishments, even though skill needs in the former are generally lower and the relative skills of black applicants there are likely higher. The sources of prejudice underlying the discrimination, however, are not identified. Other causes of the continuing "spatial mismatch" might include transportation difficulties of inner-city blacks and/or information limitations (Holzer, Ihlanfeldt, and Sjoquist 1994; Ihlanfeldt 1996). 
Second, declining employment in manufacturing and the growth in services employment may have increased the proportion of jobs requiring face-to-face contact with consumers. If consumer discrimination exists, growth in consumer contact may help to explain recent relative declines in the relative earnings and employment of blacks (e.g., Bound and Freeman 1992).

This paper provides some new evidence on consumer discrimination in the labor market obtained from a unique new survey of employers. In contrast to previous work, the data allow a more direct examination of the issue across a more representative sample of firms and newly filled jobs. Effects on both wages and employment are provided, and some indirect evidence is provided of the possible effects of customer discrimination on trends over time in the relative employment and earnings of minorities.

Before presenting the evidence, we briefly review the previous literature on this notion and present a model of how consumer discrimination might affect the hiring of minorities.

\section{PREVIOUS LITERATURE}

Several previous studies have provided evidence on consumer discrimination in the labor market. ${ }^{3}$ Kahn and Sherer (1988) find a 20 percent wage gap between black and white professional basketball players, controlling for a variety of productivity and market-related variables and for the endogeneity of player draft position. They also find a strong positive relationship between home attendance and the proportion of team members who are white. They conclude that the compensation and attendance results together are consistent with the idea of consumer discrimination. Nardinelli and Simon (1990) find that the baseball cards of white players command a higher price than those of black players, controlling for career performance. They conclude that their evidence supports the hypothesis of consumer discrimination, since in contrast to studies that use salaries, there is no room for owner or coworker discrimination.

${ }^{3}$ Evidence of consumer discrimination in the housing market is reviewed by Yinger (1995). 
Somewhat more general but also more indirect evidence of consumer discrimination appears in Ihlanfeldt and Sjoquist (1991). They find that the racial composition of the subcounty areas defined for the 1980 Public Use Microdata Sample (PUMS) affects the occupations held by blacks who work in these areas. As the percentage of the population that is black increases, both male and female blacks have a lower likelihood of being employed in blue-collar occupations and a greater likelihood of employment in white-collar occupations, controlling for the worker's education and experience. Since white-collar occupations involve, on average, more interaction with customers than blue-collar occupations, Ihlanfeldt and Sjoquist concluded that their results are consistent with consumer discrimination.

Ihlanfeldt and Young (1994) find that the wages of black fast-food restaurant workers vary with the percentage of customers who are white, holding constant a range of variables describing the individual and the establishment. The effect, while statistically significant, is small in magnitude: a 10 percentage point increase in the percentage of customers who are white reduces wages by 1 percent.

Although all of the above studies suggest that consumer discrimination against blacks exists, Kenney and Wissoker's (1994) analysis of hiring audit data provides no evidence that consumer discrimination exists against Hispanics. They find that the treatment of Hispanic versus white auditors is not influenced by the racial composition of the neighborhood where the firm is located. On the other hand, an audit study by Neumark (1996) finds that females are less likely than males to be hired at high-price restaurants.

To summarize the above evidence on consumer discrimination, it has been either fragmentary (based on very specific industry and occupational categories) or quite indirect. 


\section{A MODEL OF CONSUMER DISCRIMINATION}

In Becker's (1971) original discussion of consumer discrimination, blacks and whites produce goods separately in a competitive product market. The price of goods produced by the former, as well as their wages, are simply reduced by amounts proportional to the relevant "discrimination coefficient" among consumers. $^{4}$

We present a much more general model of such discrimination, where employers choose the racial composition of their workforce in response to the prejudices of their customers. ${ }^{5}$ Unlike Becker, we do not assume complete segregation of the workforce or perfect competition in the product market, though either of these might be considered special cases of our model. In addition to the prejudices of white customers, we also allow for the possibility that prejudice against workers of another minority group (or in favor of their own group) might exist among minority customers.

We assume that there are two racial groups, whites and blacks (denoted by W and B). Firms face separate product demand functions between the two groups of consumers, and must hire from among the two types of workers. Each group prefers to buy from workers of their own racial group. For simplicity, we assume that workers from each group are equally productive, and each produce one unit of output per period.

A firm's profits in any period can be represented by:

$$
\Pi=P\left[Q_{W}(P, r)+Q_{B}(P, r)\right]-E_{B} r\left(Q_{W}+Q_{B}\right)-E_{W}(1-r)\left(Q_{W}+Q_{B}\right)
$$

\footnotetext{
${ }^{4}$ If racial tastes vary among consumers, the least prejudiced consumers would first buy products produced by blacks, and the relevant market coefficient would reflect the tastes of the marginal consumer choosing between products produced by blacks and whites. Borjas and Bronars (1989) also present a model of consumer discrimination with a fixed discrimination coefficient among white customers, but with imperfect information about product prices and race of the seller that generates a distribution of product prices in equilibrium and differential selection by race into self-employment.
}

${ }^{5}$ We thank Carl Davidson for his assistance in generating this model. 
where $\mathrm{P}$ and Q represent price and output respectively, $\mathrm{r}$ represents the fraction of the firm's workforce that is black, and $\mathrm{E}_{\mathrm{W}}$ and $\mathrm{E}_{\mathrm{B}}$ represent the wages of whites and blacks respectively. The demand function is shifted by $\mathrm{r}$ - positively for black consumers and negatively for white customers, that is, $\mathrm{dQ}_{\mathrm{W}} / \mathrm{dr}<0$ and $\mathrm{dQ}_{\mathrm{B}} / \mathrm{dr}>0$.

Differentiating Equation (1) with respect to $\mathrm{P}$ and $\mathrm{r}$ yields the following first-order conditions:

$$
\begin{gathered}
\mathrm{Q}_{\mathrm{W}}+\mathrm{Q}_{\mathrm{B}}+\left[\mathrm{P}-\mathrm{rE}_{\mathrm{B}}-(1-\mathrm{r}) \mathrm{E}_{\mathrm{W}}\right]\left[\partial \mathrm{Q}_{\mathrm{W}} / \partial \mathrm{P}+\partial \mathrm{Q}_{\mathrm{B}} / \partial \mathrm{P}\right]=0 \\
\left(\mathrm{E}_{\mathrm{W}}-\mathrm{E}_{\mathrm{B}}\right)\left(\mathrm{Q}_{\mathrm{W}}+\mathrm{Q}_{\mathrm{B}}\right)+\left[\mathrm{P}-\mathrm{rE}_{\mathrm{B}}-(1-\mathrm{r}) \mathrm{E}_{\mathrm{W}}\right]\left(\partial \mathrm{Q}_{\mathrm{W}} / \partial \mathrm{r}+\partial \mathrm{Q}_{\mathrm{B}} / \partial \mathrm{r}\right)=0
\end{gathered}
$$

Equation (2) is a variant of the usual profit-maximizing condition for monopolistic sellers (in which marginal revenue is equated with marginal cost). The second term of Equation (3) implies that the firm equates the marginal revenue and cost associated with hiring blacks, while the first term allows for the possibility that higher wages among whites will lead the firm to substitute black for white workers. ${ }^{6}$

By totally differentiating the first-order conditions with respect to $\mathrm{P}$ and $\mathrm{r}$ and then solving simultaneously, it can be shown that $r$ is a negative function of $\mathrm{Q}_{\mathrm{W}}$ and a positive function of $\mathrm{Q}_{\mathrm{B}}$. Thus, anything which raises the former relative to the latter will tend to reduce the presence of blacks in the firm's workforce. ${ }^{7}$ For instance, if the firm is located within a predominantly white residential neighborhood (and therefore has a predominantly white clientele), blacks should be a smaller proportion of the firm's workforce. Of course, the reverse would be true if the firm is located within a predominantly black neighborhood. ${ }^{8}$ A tendency for firms to relocate over time away from black areas towards white areas

${ }^{6}$ Despite the equal productivities of white and black workers, marketwide wage differentials between them might exist due to discrimination. Since the labor market is competitive, any firm takes these wages as given when determining its own hiring.

${ }^{7}$ This can be easily demonstrated if, for example, we assume a demand function for each group that is linear in the log of output with respect to $\mathrm{r}$. Then $\mathrm{dQ} / \mathrm{dr}$ for each group is proportional to the quantity of output consumed by each.

${ }^{8}$ Implicitly, the model assumes perfectly elastic supplies of white and black labor to all firms; thus, any racial disparities in hiring are caused by the hiring choices of employers. If the model allowed for the relative supplies of labor to depend on a firm's location (due to commuting costs, for instance), the degree of workforce segregation will be even greater. 
would therefore tend to reduce the relative demand for black labor, as the "spatial mismatch" hypothesis implies.

In the presence of a high degree of residential segregation, we might find corner solutions in which the workforces of firms are completely segregated, as in Becker; but other costs and legal constraints might limit the extent to which such workforce segregation is desirable or possible. ${ }^{9}$ Even with comparable numbers of white and black customers, the relatively higher incomes of white customers might imply a greater presence of white workers among firms in racially mixed neighborhoods; the employment benefits associated with residential integration for blacks might therefore be limited. Other characteristics of the two demand functions, such as potential nonlinearities with respect to the presence of black workers, will also determine the extent to which residential integration improves the employment prospects of blacks. ${ }^{10}$

The above theoretical model, while simplistic, is useful in various respects. First, it provides some justification for the empirical specification that we use below; namely, the fractions of a firm's employees that are black and Hispanic are functions of the percentages of the firm's customers who are black and Hispanic. Second, the theory could easily be extended to incorporate the notion that the racial composition of the firm's customers may have differential effects depending on the tasks performed by workers or the occupational category in which they work. ${ }^{11}$ The latter follows from the idea that consumers may be less

${ }^{9}$ For some economic analysis of the costs of residential segregation to blacks see Yinger (1995). Consistent with our analysis, Cutler and Glaeser (1995) point out that there could be both costs and benefits to specific ethnic groups from segregation, though their empirical estimates suggest that the costs to blacks clearly outweigh the benefits. The possibility that residential integration might actually reduce job prospects for blacks was also pointed out by Offner and Saks (1971).

${ }^{10}$ For instance, the consumers of one group may not mind a limited presence of the other group in shops that they frequent, but they become more uncomfortable when that presence rises above a certain level. Under these circumstances, the degree of workforce integration that we observe should be limited. If the effects of employee race in each group's product demand function are constant, and if no other factors differentially affect relative product demand between the two groups, then workforce integration should occur commensurate with residential integration, and the latter will not impede employment prospects of minorities.

${ }^{11}$ This notion could be incorporated into the model by allowing product demand for each racial group to be functions of $\mathrm{r}_{\mathrm{j}}$, and for some particular occupation groups $\mathrm{j}$, rather than $\mathrm{r}$ more generally. 
prejudiced against workers of the nonpreferred group if these workers do not hold higher-status jobs or jobs involving direct contact with customers.

\section{DATA AND ESTIMATION ISSUES}

The data used in this paper are drawn from a new survey of employers that was administered between June 1992 and May 1994 to over 3,000 employers in four large metropolitan areas: Atlanta, Boston, Detroit, and Los Angeles. The survey was administered over the phone to individuals responsible for hiring, and focused on the characteristics of overall employees, vacant jobs, and the most recently filled job and hired worker at each establishment. Other characteristics of the establishment, such as its size, presence of collective bargaining, and the demographic composition of its applicants and customers, were gauged as well.

The sample of firms surveyed was drawn from two sources: roughly 30 percent were generated by employees who were respondents in a household survey in the same four metropolitan areas; and the rest were generated by lists provided by Survey Sampling Inc. (SSI). ${ }^{12}$ The latter sample was stratified ex ante to reflect the distribution of workers across establishment sizes in the labor force; while the former sample implicitly reflects this distribution. Both samples are therefore weighted by employee size, permitting analysis of either individual jobs (such as the one most recently filled) at these firms or overall employment. ${ }^{13}$ Response rates to the survey among firms that passed the screening averaged 67 percent, and there is little evidence of selection bias induced by nonrandom response patterns in the data. ${ }^{14}$

\footnotetext{
${ }^{12}$ For analysis of data from another survey of firms drawn from SSI samples of employers see Barron, Black, and Berger 1994. The household and employer surveys in the four metropolitan areas are part of the MultiCity Study of Urban Inequality (MCSUI) funded by the Ford and Russell Sage Foundations.

${ }^{13}$ Sample weights are still necessary when analyzing summary data, to adjust for the deliberate underrepresentation of jobs requiring college in the sample as well as for various characteristics of the household samples that generated some of the firms.

${ }^{14}$ Since SSI provided data on industry, location, and establishment size for all firms, we could test for differences in response rates across these observable dimensions. We found only small and/or insignificant
} 
The estimated equations that we present below are generally of the following form:

$$
\begin{gathered}
\mathrm{R}_{\mathrm{jk}}=\alpha+\beta \operatorname{CUS}_{\mathrm{jk}}+\gamma \mathrm{X}_{\mathrm{j}}+\delta \mathrm{X}_{\mathrm{k}}+\epsilon_{\mathrm{jk}} \\
\mathrm{W}_{\mathrm{ijk}}=\lambda+\eta \operatorname{CUS}_{\mathrm{jk}}+\theta \mathrm{X}_{\mathrm{j}}+\rho \mathrm{X}_{\mathrm{k}}+\sigma \mathrm{X}_{\mathrm{i}}+v_{\mathrm{ijk}}
\end{gathered}
$$

where R denotes race (white, black, or Hispanic) of hired workers and W denotes the log of the starting wage; CUS represents variables for the percentages of the firm's customers who are black and Hispanic; the $\mathrm{X}$ reflect a variety of control variables; and i, $\mathrm{j}$, and $\mathrm{k}$ denote the last worker hired, the last job filled, and the firm (or establishment) respectively.

CUS is measured by responses to the survey questions, "What percentage of the customers at your firm are ___?", where the question was asked repeatedly for blacks, Hispanics, and Asians. ${ }^{15} \mathrm{We}$ analyze the effects of the racial composition of customers on the race of employees through two different versions of Equation (4): one in which the dependent variable is the fraction of black or Hispanic workers at the establishment, ${ }^{16}$ and another in which the dependent variable is the race of the last worker hired. The $\mathrm{X}_{\mathrm{j}}$ variables are omitted from the former set of equations.

While the equations for the racial composition of employees are more consistent with the theoretical model presented above, those for the last worker hired have a number of advantages. First, the $\mathrm{X}_{\mathrm{j}}$ variables can be used to control more fully for job characteristics (such as skill requirements) that might be correlated with both race of customers and employees; thus, estimates using this variable are less likely to be plagued by bias from unobserved heterogeneity across firms and jobs. Second, the model above

differences in most cases. The distributions of our establishments across industries and size categories are quite comparable to those found in County Business Patterns data in the same areas, and occupational distributions are also comparable to those found in the 1990 Census of Populations. For more information see Holzer (1996b).

${ }^{15} \mathrm{We}$ do not distinguish between whites and Asians in any of this work, since we found little evidence of customer composition effects on employment across these two groups.

${ }^{16}$ Racial composition of the workforce is defined only for the noncollege employees of each establishment, though these constitute roughly 90 percent of the unweighted new hires as well. 
implies that the race of customers is likely to be endogenous with respect to the racial composition of employees, but this should be much less true with respect to the last hired worker in the establishment. ${ }^{17}$

In some versions of Equation (4), we allow for separate effects of customer composition on white, black, and Hispanic employees; in these cases, variables measuring percentage black customers and percentage Hispanic customers are included among the independent variables to allow for cross-group as well as own-group effects. Other equations focus only on blacks versus nonblacks among customers and employees. The customer variables are alternatively entered in continuous and categorical form (e.g., 0-25 percent, 26-50 percent, etc.) in all estimated equations, where the latter are used to capture non-linearities in the customer composition effects.

One of the most attractive aspects of our data is that a wide range of controls are included among the $\mathrm{X}_{\mathrm{j}}$ and $\mathrm{X}_{\mathrm{k}}$ variables. The $\mathrm{X}_{\mathrm{j}}$ include 1-digit occupation dummies and a variety of dummy variables for the hiring requirements of jobs and the cognitive/social tasks performed on these jobs-e.g., whether high school and/or college degrees, specific experience, and previous training are required, and whether the job entails daily performance of reading/writing, arithmetic, or computer use. ${ }^{18}$ The $X_{k}$ include 1-digit industry, establishment size, presence of collective bargaining, and geographic location both between and within the various metropolitan areas. Along with the $X_{j}$ and $X_{k}$ variables, the wage equations also include the $X_{i}$ controls for the personal characteristics of those hired: educational attainment, age, and gender.

The controls for firm location within the MSA are particularly important, since intrametropolitan location is expected to be highly correlated with both customer composition and the presence of minorities

\footnotetext{
${ }^{17}$ If the racial composition of customers and the hiring process are time-invariant, there should be no essential difference between the two sets of estimates (except for the possible effects of the job-specific control variables). To the extent that there is variance over time in these measures, the race of the last hired worker would be the more appropriate measure conceptually, as it shows the effect of the current composition of customers on current hiring. The correlation of the two employment measures for blacks is roughly 0.6, potentially indicating some time variance in the employment process. 1996b).

${ }^{18}$ For more evidence on these variables and their effects on employment outcomes see Holzer (1996a,
} 
in the pool of labor facing the firm. We therefore include several variables to measure this location: a dummy for whether the establishment is located within the central city; a set of dummies for being within a quarter- or half-mile of a public transit stop; and, most importantly, the distance of the establishment to the locations of the white, black, and Hispanic residents in the metro area. ${ }^{19}$

To more fully control for the supply of minority labor to any particular establishment, we can include controls for the fractions of the establishment's job applicants who are black and Hispanic. We can also include the race of the survey respondent (who was responsible for hiring at the establishment), to control for possible employer prejudice in hiring that might exist independently of customer discrimination effects. But both of these variables might themselves be functions of the racial composition of customers, and both, along with the race of customers, might simply reflect the geographic location of the establishment within the metropolitan area. ${ }^{20}$ Therefore, results are presented for three specifications of each equation: one without any controls for location within the metro area or race of applicants and respondents (but with controls for job and firm characteristics more generally); one that adds controls for location; and one that also adds controls for race of applicants and respondents. These different estimates are provided in an attempt to identify the lower and upper bounds to the true ones.

\footnotetext{
${ }^{19}$ This distance is measured as a weighted average of the distances from the census tract in which the establishment is located to every other census tract in the area, where the weights are the percentages of the area's blacks or Hispanics that are located in each of the other tracts.

These locational variables might conceivably have served as instruments for the customer variables in equations for the racial composition of all employees at the firm. However, it seems unlikely that they would be uncorrelated with the error term in these equations, since establishment location appears to be correlated with discrimination on the part of the employer. This might occur either because discriminatory employerschoose to locate away from minority populations (Mieszkowski and Mills 1993), because proximity to minorities might raise employer concern about legal actions by minority applicants (Bloch 1994), or because proximity to minorities reduces negative stereotypes by the employer. For evidence on these issues see Holzer 1996b and Holzer and Ihlanfeldt 1996.

${ }^{20}$ The racial composition of applicants to a firm might well reflect the racial preferences of the firm and its customers, since most job search models posit that expected employment outcomes influence how much or where workers search for jobs (e.g., Holzer 1988; Holzer, Katz, and Krueger 1991); in other words, thesupply of workers to a firm adjusts to attributes of demand. The race of the person responsible for hiring might reflect previous hiring patterns, caused in part by customer preferences.
} 
There are some additional sources of variation in the effects of customer preferences that we also wanted to capture here. For instance, the role of customer preferences in hiring is expected to be smaller in jobs where employees have little direct contact with customers; this may also be true in lower-status jobs - that is, customers may object less to seeing the nonpreferred group in blue-collar or service jobs in comparison to higher-level positions. Also, it may be the prejudices of minority customers that drive employment outcomes, in addition to (or instead of) those of whites.

To deal with the possibility that customer racial preferences may be relatively more important in some jobs than others, estimates are provided from equations in which we interact race of customers with a set of occupation dummies, and also (in some equations) a variable for whether or not the job involves faceto-face contact with customers. Under the assumption that some of these jobs, such as those that do not involve contact, are subject to little or no customer discrimination, we can generate "difference-indifference" estimates of the effects of customer composition — that is, estimates of the differences between effects for jobs that do and do not involve direct customer contact. Under certain assumptions, these estimates will be largely purged of unobserved heterogeneity across firms and/or jobs.

The interactions between the direct contact variables and the categorical measures of customer racial composition (which define firms as having predominantly white, predominantly black, or racially mixed customers) are also used to distinguish between white and black customer prejudice, as explained more fully below.

\section{EMPIRICAL RESULTS}

\section{$\underline{\text { Summary Statistics }}$}

Table 1 presents summary data on the racial composition of customers in each of the four metropolitan areas. The data include means (and standard deviations) on the percentages of each establishment's customers who are black or Hispanic. Also reported are the distributions of establishments across quartile categories of black and Hispanic customers. The data are presented for all firms and 
separately by central city/suburbs for the full sample and for each MSA. All means and tabulations are sample-weighted.

The results show that blacks and Hispanics constitute approximately 18 percent and 14 percent, respectively, of the customers in the full sample of establishments. Thus, a strong majority (over twothirds) of the customers in these firms are white. Indeed, blacks constitute a fourth or fewer of all customers in over 70 percent of the establishments, while the comparable number for Hispanics is over 80 percent.

Percentages of black customers are somewhat higher in Atlanta and Detroit than in Boston and Los Angeles, while the opposite is true for Hispanics. Black customers are also more heavily concentrated in firms located in the central cities than in the suburbs. ${ }^{21}$ All of these characteristics strongly parallel the presence of blacks and Hispanics in the relevant residential populations for these areas. ${ }^{22}$ But, even in the central cities, blacks are the majority of customers in just 16 percent of all establishments (a figure that rises to 44 percent in central-city Detroit). The comparable figure for Hispanics is 10 percent (and 22 percent in Los Angeles).

\footnotetext{
${ }^{21}$ The "suburbs" here include all areas outside of the primary central city in each metro area, such as other central cities (e.g., Pontiac and Dearborn in the Detroit MSA, Marietta in the Atlanta MSA, and Cambridge and others in Boston) and heavily black residential areas outside of the central cities. When the latter are omitted from suburban areas, the percentages of black customers in the suburbs declines from 16 percent to just under 15 percent.

${ }^{22}$ For instance, blacks and Hispanics constitute an (unweighted) average of roughly 17 percent and 12 percent of the respective populations in these four metro areas.
} 
TABLE 1

Racial Composition of Customers: Summary Statistics

\begin{tabular}{|c|c|c|c|c|c|c|c|c|c|c|c|c|c|c|c|}
\hline & \multicolumn{3}{|c|}{ All Four MSAs } & \multicolumn{3}{|c|}{ Atlanta } & \multicolumn{3}{|c|}{ Boston } & \multicolumn{3}{|c|}{ Detroit } & \multicolumn{3}{|c|}{ Los Angeles } \\
\hline & TOT & $\mathrm{CC}$ & SUB & TOT & $\mathrm{CC}$ & SUB & TOT & $\mathrm{CC}$ & SUB & TOT & $\mathrm{CC}$ & SUB & TOT & $\mathrm{CC}$ & SUB \\
\hline \multicolumn{16}{|l|}{ Blacks } \\
\hline Mean & .183 & .231 & .165 & .259 & .321 & .236 & .132 & .215 & .114 & .216 & .395 & .181 & .136 & .142 & .132 \\
\hline (S.D.) & $(.214)$ & $(.239)$ & $(.198)$ & $(.238)$ & $(.268)$ & $(.219)$ & (.169) & $(.214)$ & $(.148)$ & $(.247)$ & $(.263)$ & $(.225)$ & $(.162)$ & $(.157)$ & $(.165)$ \\
\hline \multicolumn{16}{|c|}{ Distribution } \\
\hline $.01-.25$ & .716 & .613 & .753 & .549 & .473 & .577 & .826 & .628 & .869 & .659 & .390 & .705 & .814 & .748 & .859 \\
\hline $.26-.50$ & .184 & .227 & .164 & .278 & .273 & .280 & .115 & .214 & .093 & .192 & .171 & .196 & .151 & .213 & .109 \\
\hline $.51-.75$ & .069 & .097 & .058 & .119 & .141 & .111 & .049 & .115 & .034 & .089 & .209 & .069 & .024 & .035 & .017 \\
\hline $.76-1.00$ & .031 & .064 & .020 & .054 & .113 & .032 & .011 & .043 & .004 & .059 & .229 & .030 & .011 & .003 & .015 \\
\hline \multicolumn{16}{|l|}{ Hispanics } \\
\hline Mean & .135 & .177 & .120 & .057 & .051 & .060 & .093 & .123 & .086 & .044 & .056 & .042 & .305 & .310 & .302 \\
\hline (S.D.) & $(.215)$ & $(.251)$ & $(.195)$ & $(.071)$ & $(.070)$ & $(.071)$ & $(.138)$ & $(.133)$ & (.139) & $(.066)$ & $(.054)$ & $(.069)$ & $(.303)$ & $(.336)$ & $(.277)$ \\
\hline \multicolumn{16}{|c|}{ Distribution } \\
\hline $.01-.25$ & .809 & .736 & .835 & .963 & .960 & .964 & .908 & .855 & .919 & .976 & .949 & .981 & .467 & .493 & .448 \\
\hline $.26-.50$ & .125 & .161 & .112 & .034 & .035 & .034 & .071 & .121 & .061 & .020 & .051 & .015 & .326 & .286 & .353 \\
\hline $.51-.75$ & .031 & .032 & .030 & .003 & .005 & .002 & .008 & .009 & .008 & .003 & .000 & .004 & .096 & .067 & .116 \\
\hline $.76-1.00$ & .035 & .070 & .023 & .000 & .000 & .000 & .013 & .016 & .013 & .000 & .000 & .000 & .112 & .154 & .083 \\
\hline
\end{tabular}

Note: All means are sample-weighted. "CC" and "SUB" refer to firms located in the central city and suburbs of each metropolitan area, respectively. 
As the theoretical model above suggests, the predominance of white customers in the vast majority of establishments accounting for new employment could lead to major negative effects on the employment or earnings of minority workers. Even if the preferences of minority consumers are as strong as those of whites, the relatively small number of establishments that have majorities of customers who are black or Hispanic implies that whites may be less disadvantaged by consumer discrimination than minority groups.

\section{Estimated Equations for Race of Employees and Last Hired Worker}

Tables 2 and 3 present results from estimated versions of Equation (4) for the race of employees hired at these establishments as functions of the racial composition of customers. In Table 2, the results are from equations in which the dependent variable is either the percentage of employees who are black or those who are Hispanic; the equations are estimated using the Tobit functional form. ${ }^{23}$ Table 3 reports the estimated effects of customer racial composition on the probability that the last hired worker was black, Hispanic, or white (reference group) obtained from multinomial logit equations.

The results from equations in which the percentages of customers who are black or Hispanic enter in continuous form are reported at the top of each of these tables, while the results with the quartile dummies appear at the bottom. One column of estimates is presented for each of the three specifications described above - that is, Column 1 omits controls for location within the MSA and race of applicants and respondents; Column 2 includes controls for location within the MSA; and Column 3 includes all of these variables. Underneath each of the estimated logit coefficients is the standard error (in parentheses) and partial derivative evaluated at the sample means (in brackets). Controls for other establishment characteristics are included in all three specifications, as are controls for characteristics of jobs in the results reported in Table 3.

\footnotetext{
${ }^{23}$ Estimated customer composition effects are generally a bit larger using the Tobit model than those estimated by OLS, though qualitatively the two sets of results are virtually identical.
} 
TABLE 2

Effects of Customer Composition on Race of Employees: Tobit Estimates (Standard Errors in Parentheses)

\begin{tabular}{|c|c|c|c|c|c|c|}
\hline & \multicolumn{3}{|c|}{ Blacks } & \multicolumn{3}{|c|}{ Hispanics } \\
\hline & 1 & 2 & 3 & 1 & 2 & 3 \\
\hline \multicolumn{7}{|c|}{ Percent Customers } \\
\hline Black & $\begin{array}{l}.0077 \\
(.0003)\end{array}$ & $\begin{array}{l}.0064 \\
(.0003)\end{array}$ & $\begin{array}{c}.0031 \\
(.0003)\end{array}$ & $\begin{array}{l}-.0003 \\
(.0003)\end{array}$ & $\begin{array}{l}-.0007 \\
(.0003)\end{array}$ & $\begin{array}{l}-.0002 \\
(.0003)\end{array}$ \\
\hline Hispanic & $\begin{array}{l}-.0016 \\
(.0005)\end{array}$ & $\begin{array}{l}-.0015 \\
(.0005)\end{array}$ & $\begin{array}{l}-.0003 \\
(.0004)\end{array}$ & $\begin{array}{l}.0056 \\
(.0004)\end{array}$ & $\begin{array}{l}.0055 \\
(.0004)\end{array}$ & $\begin{array}{l}.0023 \\
(.0004)\end{array}$ \\
\hline$-\log \mathrm{L}$ & 572.25 & 512.02 & 300.58 & 448.35 & 426.48 & 234.76 \\
\hline \multicolumn{7}{|l|}{ Percent Black } \\
\hline $.26-.50$ & $\begin{array}{l}.166 \\
(.018)\end{array}$ & $\begin{array}{l}.127 \\
(.018)\end{array}$ & $\begin{array}{l}.066 \\
(.016)\end{array}$ & $\begin{array}{l}.006 \\
(.018)\end{array}$ & $\begin{array}{l}-.001 \\
(.018)\end{array}$ & $\begin{array}{c}.007 \\
(.015)\end{array}$ \\
\hline $.51-.75$ & $\begin{array}{l}.326 \\
(.024)\end{array}$ & $\begin{array}{l}.251 \\
(.024)\end{array}$ & $\begin{array}{l}.109 \\
(.022)\end{array}$ & $\begin{array}{l}.020 \\
(.024)\end{array}$ & $\begin{array}{c}.002 \\
(.025)\end{array}$ & $\begin{array}{l}.009 \\
(.022)\end{array}$ \\
\hline $.76-1.00$ & $\begin{array}{l}.600 \\
(.030)\end{array}$ & $\begin{array}{c}.492 \\
(.030)\end{array}$ & $\begin{array}{l}.233 \\
(.029)\end{array}$ & $\begin{array}{l}-.007 \\
(.033)\end{array}$ & $\begin{array}{l}-.036 \\
(.034)\end{array}$ & $\begin{array}{l}-.008 \\
(.030)\end{array}$ \\
\hline $\begin{array}{r}\text { Percent Hisp } \\
.26-.50\end{array}$ & $\begin{array}{l}-.038 \\
(.025)\end{array}$ & $\begin{array}{l}-.028 \\
(.024)\end{array}$ & $\begin{array}{l}-.016 \\
(.021)\end{array}$ & $\begin{array}{c}.089 \\
(.021)\end{array}$ & $\begin{array}{c}.083 \\
(.021)\end{array}$ & $\begin{array}{l}.029 \\
(.018)\end{array}$ \\
\hline $.51-.75$ & $\begin{array}{l}-.048 \\
(.042)\end{array}$ & $\begin{array}{l}-.043 \\
(.040)\end{array}$ & $\begin{array}{l}-.018 \\
(.036)\end{array}$ & $\begin{array}{l}.222 \\
(.034)\end{array}$ & $\begin{array}{l}.208 \\
(.034)\end{array}$ & $\begin{array}{l}.086 \\
(.029)\end{array}$ \\
\hline $.76-1.00$ & $\begin{array}{l}-.103 \\
(.049)\end{array}$ & $\begin{array}{l}-.111 \\
(.047)\end{array}$ & $\begin{array}{c}.014 \\
(.044)\end{array}$ & $\begin{array}{c}.466 \\
(.039)\end{array}$ & $\begin{array}{c}.447 \\
(.039)\end{array}$ & $\begin{array}{l}.170 \\
(.035)\end{array}$ \\
\hline$-\log L$ & 606.10 & 537.29 & 308.39 & 462.28 & 440.81 & 240.85 \\
\hline
\end{tabular}

Note: Sample size is 1922 . Column 1 estimates include controls for MSA, industry, and establishment size. Column 2 equations also include controls for location with the MSA, while Column 3 includes these variables plus race of applicants and survey respondent. 
TABLE 3

Effects of Customer Composition on Race of Last Hire: Multinomial Logit Estimates

\begin{tabular}{|c|c|c|c|c|c|c|}
\hline & & Blacks & & & Hispani & \\
\hline & 1 & 2 & 3 & 1 & 2 & 3 \\
\hline Percent Custo & & & & & & \\
\hline Black & .045 & .037 & .024 & .001 & -.000 & -.002 \\
\hline & $(.003)$ & $(.003)$ & $(.004)$ & $(.005)$ & $(.005)$ & $(.006)$ \\
\hline & {$[.006]$} & {$[.005]$} & {$[.003]$} & {$[-.001]$} & {$[-.001]$} & {$[-.001]$} \\
\hline Hispanic & -.009 & -.007 & -.009 & .026 & .025 & .013 \\
\hline & $(.007)$ & $(.007)$ & $(.007)$ & $(.004)$ & $(.004)$ & $(.005)$ \\
\hline & {$[-.002]$} & {$[-.002]$} & {$[-.002]$} & {$[.004]$} & {$[.003]$} & {$[.002]$} \\
\hline Percent Black & & & & & & \\
\hline $.26-.50$ & 1.049 & .833 & .564 & .161 & .122 & .126 \\
\hline & $(.164)$ & $(.170)$ & $(.180)$ & $(.225)$ & $(.230)$ & $(.239)$ \\
\hline & {$[.143]$} & [.114] & {$[.076]$} & {$[-.006]$} & [-.006] & {$[.002]$} \\
\hline $.51-.75$ & 1.933 & 1.541 & .943 & .038 & -.055 & -.211 \\
\hline & $(.204)$ & $(.215)$ & $(.231)$ & $(.395)$ & $(.405)$ & $(.428)$ \\
\hline & {$[.270]$} & [.218] & [.138] & {$[-.045]$} & {$[-.047]$} & {$[-.052]$} \\
\hline $.76-1.00$ & 3.428 & 2.790 & .743 & .475 & .210 & -.214 \\
\hline & $(.304)$ & $(.313)$ & $(.344)$ & $(.744)$ & $(.783)$ & $(.786)$ \\
\hline & [.469] & {$[.386]$} & {$[.250]$} & {$[-.027]$} & {$[-.045]$} & {$[-.073]$} \\
\hline Percent Hispa & & & & & & \\
\hline $.26-.50$ & -.211 & -.175 & -.244 & .569 & .561 & .286 \\
\hline & $(.254)$ & $(.260)$ & $(.276)$ & $(.220)$ & $(.225)$ & $(.237)$ \\
\hline & {$[-.044]$} & {$[-.039]$} & {$[-.042]$} & [.079] & {$[.077]$} & {$[.043]$} \\
\hline $.51-.75$ & -.233 & -.236 & -.413 & .931 & .828 & .272 \\
\hline & $(.477)$ & $(.485)$ & $(.516)$ & $(.328)$ & $(.336)$ & $(.358)$ \\
\hline & {$[-.057]$} & {$[-.055]$} & {$[-.065]$} & [.127] & [.113] & [.046] \\
\hline $.76-1.00$ & -.044 & .019 & .139 & 2.172 & 2.095 & .955 \\
\hline & $(.859)$ & $(.852)$ & $(.936)$ & $(.437)$ & $(.452)$ & $(.502)$ \\
\hline & [-.062] & [-.052] & [-.005] & {$[.283]$} & {$[.271]$} & [.120] \\
\hline
\end{tabular}

Note: Estimated partial derivatives evaluated at sample means are in brackets. Columns are defined as in the previous table, except that all equations also include controls for job-specific skill needs and occupation dummies. 
The results of Tables 2 and 3 show that the presence of black or Hispanic customers at an establishment has significant positive effects on the hiring of employees from these groups. The magnitudes of these effects are somewhat reduced when controls are added for location and decline even more when the other racial variables are included, but the effects generally remain statistically significant. ${ }^{24}$ Effects estimated for blacks are generally larger than those estimated for Hispanics, suggesting either a stronger antipathy among white customers for the former or a stronger preference among black customers for employees of their own race.

The partial derivatives evaluated at sample means indicate that a twenty-percentage point (or roughly one standard-deviation) increase in the fraction of customers who are black increases the probability that blacks will be hired by $6-12$ percentage points in Table 3 (or $15-30$ percent of a standard deviation), and 6-15 points in Table $2 .{ }^{25}$ For Hispanics, the comparable effects would be $4-8$ percentage points. ${ }^{26}$ Furthermore, while the own-group effects are all positive, the cross-group effects between blacks and Hispanics are generally negative but not significant. The results thus suggest that customers from each group prefer employees of their own group to those from other groups, while both blacks and Hispanics do not appreciably distinguish the other minority group from whites.

The estimates using the quartile categories for racial composition of customers as independent variables also show that effects of customer racial composition rise monotonically for both blacks and Hispanics, with employment probabilities being significantly higher than for the omitted group (that is,

\footnotetext{
${ }^{24}$ The correlations between race of customers and the distance of the firm to the residential locations of each group are roughly 0.2 to 0.3 , thereby indicating a good deal of independent variation between the two. Correlations between the racial composition of customers, applicants, and race of respondent are generally 0.5 to 0.6 .

Since the customer composition variables are undoubtedly measured with some error, the estimates presented in Tables 2 and 3 likely understate the true effects of these variables.

${ }^{25}$ Comparing the partial derivatives of Table 3 to the coefficient estimates of Table 2, we find that the latter are generally larger for the first specification but not for the third.

${ }^{26}$ The sample-weighted fractions of all new jobs filled by blacks and Hispanics are 0.169 and 0.153 respectively, with standard deviations of 0.409 and 0.393 .
} 
customers who are no more that one-fourth black or Hispanic) in each category. The results also suggest some non-linearity in these effects—-specifically, the probability of hiring each minority group rises substantially at establishments where the group's customers constitute three-fourths or more of the total.

Although not reported for reasons of space, separate estimates were also generated for particular subsets of the sample. First, the sample was stratified by whether or not the firm is part of the retail trade sector. Results did not differ significantly between the retail trade and other sectors, even though the customers in the former sector are more likely to be private consumers rather than the owners or employees of other businesses. ${ }^{27}$ Second, separate estimates by gender reveal that the racial composition of customers has somewhat larger effects on the hiring of black and Hispanic females than their male counterparts, which may reflect the greater tendency of females to be found in jobs with direct customer contact. Finally, separate equations were estimated for each of the four metro areas. Estimated customer composition effects are highly similar across these areas. ${ }^{28}$

\section{Effects by Occupation and Customer Contact}

The extent to which consumers prefer dealing with employees who are members of their own racial group should matter more in some kinds of jobs than in others. For instance, white customers may not mind dealing with blacks in a low-status occupation, such as the service category. It also seems plausible that the racial composition of customers will matter more for hiring into jobs that involve direct contact with customers.

This section therefore presents estimated effects of customer racial composition interacted with occupation and/or whether the most recently filled job in the firm involves direct contact with customers. The customer contact variable is based on a survey question for how frequently individuals in the job "talk

\footnotetext{
${ }^{27}$ The same survey question for race of customers was asked of all establishments. For wholesale trade and manufacturing firms, this question likely refers to those individuals at other companies (including proprietors) who work as purchasers.
}

${ }^{28}$ More details on all of these estimates are available from the authors. 
face-to-face with customers or clients"; we define a dummy variable which equals one when jobs involve at least some customer contact and zero otherwise. ${ }^{29}$

Table 4 presents estimates from equations in which this variable and/or occupation are interacted with the categorical version of percentage black customers. ${ }^{30}$ In part A of the table, we present coefficients on interactions between customer categories and five occupation dummies, while in part B the interactions are with both occupational category and the dummy variable for customer contact. In both cases, the coefficients presented are on dummies for two-way or three-way "cells" (that is, percentage black-byoccupation or percentage black-by-contact-by-occupation) and sales jobs in predominantly white areas is used as the reference category. ${ }^{31}$

We present results from two estimated equations, corresponding to the first and third specifications used in Tables 2 and 3 (that is, omitting or including within-MSA location and other racial characteristics of the establishment). Cell sizes for the interactions are too small to separately consider Hispanics in the analysis. Results are therefore presented from estimated binomial logit equations where the dependent variable is one if a black is hired and zero otherwise.

The results of part A of Table 4 show that there are differences in the probabilities of hiring blacks across the occupational categories within each racial category of customers; there are also differences across racial categories within occupations. Regarding the first set of differences, within the

${ }^{29} \mathrm{~A}$ separate question was asked for those who talked over the phone. When we allow our variable to include this type of contact, results are fairly similar to those reported in Table 4 (since the two contact variables are quite highly correlated). These survey questions inquired whether each type of contact occurred at least daily, weekly, monthly, or not at all. Most responses fell in the first or last of these categories; thus, estimates changed very little when we redefined the contact variable as daily versus all other categories.

${ }^{30}$ The top two quartiles of the customer variable have been combined to maintain sample size.

${ }^{31}$ Since over 95 percent of the sales jobs involve direct customer contact, we include all sales jobs in the contact category. We also combine other white-collar jobs into a single category, since so few of these other whitecollar jobs involve no customer contact. 
TABLE 4

Effects of Black Customers on the Hiring of Blacks: Separate Effects by Occupation and/or Customer Contact (Binomial Logit Estimates)

\begin{tabular}{|c|c|c|c|c|c|c|}
\hline \multirow[b]{2}{*}{ Percentage Black Customers } & \multicolumn{2}{|c|}{$.00-.25$} & \multicolumn{2}{|c|}{$.26-.50$} & \multicolumn{2}{|c|}{$.51-1.00$} \\
\hline & 1 & 2 & 1 & 2 & 1 & 2 \\
\hline \multicolumn{7}{|l|}{ A. By Occupation } \\
\hline \multicolumn{7}{|l|}{ Occupation } \\
\hline \multirow[t]{2}{*}{ Sales } & - & - & $\begin{array}{l}1.657 \\
(.479)\end{array}$ & $\begin{array}{l}1.375 \\
(.523)\end{array}$ & $\begin{array}{l}3.277 \\
(.484)\end{array}$ & $\begin{array}{l}1.682 \\
(.546)\end{array}$ \\
\hline & {$[-]$} & {$[-]$} & {$[.261]$} & {$[.193]$} & {$[.460]$} & {$[.236]$} \\
\hline \multirow[t]{2}{*}{ Prof./Manag. } & .684 & .691 & 1.803 & 1.233 & 2.949 & 2.085 \\
\hline & $\begin{array}{l}(.460) \\
{[.096]}\end{array}$ & $\begin{array}{l}(.482) \\
{[.097]}\end{array}$ & $\begin{array}{l}(.498) \\
{[.253]}\end{array}$ & $\begin{array}{l}(.507) \\
{[.173]}\end{array}$ & $\begin{array}{l}(.510) \\
{[.414]}\end{array}$ & $\begin{array}{l}(.521) \\
{[.293]}\end{array}$ \\
\hline \multirow[t]{3}{*}{ Clerical } & .643 & .694 & 1.677 & 1.145 & 2.937 & 1.847 \\
\hline & $(.475)$ & $(.457)$ & $(.459)$ & $(.485)$ & $(.489)$ & $(.519)$ \\
\hline & {$[.090]$} & {$[.097]$} & {$[.236]$} & {$[.161]$} & {$[.412]$} & {$[.259]$} \\
\hline \multirow[t]{3}{*}{ Service } & 1.403 & 1.324 & 2.252 & 1.603 & 3.627 & 2.464 \\
\hline & $(.448)$ & $(.475)$ & $(.476)$ & $(.511)$ & $(.497)$ & $(.528)$ \\
\hline & {$[.197]$} & {$[.186]$} & {$[.316]$} & {$[.225]$} & {$[.509]$} & {$[.346]$} \\
\hline \multirow[t]{3}{*}{ Blue-Collar } & 1.125 & 1.148 & 1.450 & 1.254 & 2.537 & 1.342 \\
\hline & $(.443)$ & $(.467)$ & $(.506)$ & $(.540)$ & $(.530)$ & $(.571)$ \\
\hline & [.158] & {$[.161]$} & {$[.204]$} & {$[.176]$} & {$[.356]$} & [.188] \\
\hline
\end{tabular}

B. By Occupation and Customer Contact

$\begin{array}{lcccccc}\begin{array}{l}\text { Contact } \\ \text { Sales }\end{array} & - & - & 1.673 & 1.249 & 3.288 & 2.108 \\ & {[-]} & {[-]} & {[.235]} & {[.175]} & {[.462]} & {[.296]} \\ & & & & & & \\ \text { Other White-Collar } & .618 & .673 & 1.530 & 1.063 & 3.030 & 1.776 \\ & (.427) & (.448) & (.450) & (.472) & (.461) & (.491) \\ & {[.087]} & {[.095]} & {[.215]} & {[.149]} & {[.426]} & {[.249]} \\ \text { Blue-Collar } & 1.116 & 1.190 & 1.576 & 1.460 & 2.789 & 1.506 \\ & (.461) & (.485) & (.571) & (.607) & (.574) & (.618) \\ & {[.157]} & {[.167]} & {[.221]} & {[.205]} & {[.392]} & {[.212]} \\ \text { Service } & & & & & & \\ & 1.335 & 1.291 & 2.445 & 1.809 & 3.710 & 2.489 \\ & (.458) & (.486) & (.489) & (.527) & (.510) & (.542) \\ & {[.187]} & {[.181]} & {[.343]} & {[.254]} & {[.521]} & {[.350]}\end{array}$


TABLE 4, continued

\begin{tabular}{|c|c|c|c|c|c|c|}
\hline \multirow[b]{2}{*}{ Percentage Black Customers } & \multicolumn{2}{|c|}{$.00-.25$} & \multicolumn{2}{|c|}{$.26-.50$} & \multicolumn{2}{|c|}{$.51-1.00$} \\
\hline & 1 & 2 & 1 & 2 & 1 & 2 \\
\hline \multicolumn{7}{|l|}{ No Contact } \\
\hline Other White-Collar & $\begin{array}{c}.683 \\
(.485) \\
{[.096]}\end{array}$ & $\begin{array}{c}.571 \\
(.511) \\
{[.080]}\end{array}$ & $\begin{array}{c}2.273 \\
(.541) \\
{[.319]}\end{array}$ & $\begin{array}{l}1.681 \\
(.583) \\
{[.236]}\end{array}$ & $\begin{array}{c}2.390 \\
(.626) \\
{[.336]}\end{array}$ & $\begin{array}{l}1.565 \\
(.665) \\
{[.220]}\end{array}$ \\
\hline Blue-Collar & $\begin{array}{l}1.019 \\
(.497) \\
{[.143]}\end{array}$ & $\begin{array}{c}.888 \\
(.527) \\
{[.125]}\end{array}$ & $\begin{array}{l}1.204 \\
(.618) \\
{[.169]}\end{array}$ & $\begin{array}{c}.833 \\
(.671) \\
{[.117]}\end{array}$ & $\begin{array}{l}1.746 \\
(.796) \\
{[.245]}\end{array}$ & $\begin{array}{c}.710 \\
(.856) \\
{[.100]}\end{array}$ \\
\hline Service & $\begin{array}{l}1.502 \\
(.577) \\
{[.211]}\end{array}$ & $\begin{array}{l}1.212 \\
(.623) \\
{[.170]}\end{array}$ & $\begin{array}{l}1.297 \\
(.745) \\
{[.182]}\end{array}$ & $\begin{array}{c}.525 \\
(.820) \\
{[.074]}\end{array}$ & $\begin{array}{c}2.830 \\
(.927) \\
{[.397]}\end{array}$ & $\begin{array}{r}2.006 \\
(1.057) \\
{[.282]}\end{array}$ \\
\hline \multicolumn{7}{|c|}{$\underline{\text { C. Difference-in-Difference Estimates of Implied Partial Derivatives }}$} \\
\hline Sales & -.096 & -.080 & -.084 & -.061 & .126 & .076 \\
\hline Other White-Collar & -.009 & .015 & -.104 & -.087 & .090 & .029 \\
\hline Blue-Collar & .014 & .042 & .052 & .088 & .147 & .112 \\
\hline Service & -.024 & .011 & .161 & .180 & .124 & .068 \\
\hline
\end{tabular}

Note: Column 2 in this table corresponds to Column 3 in Tables 2 and 3. 
predominantly nonblack customer category, fewer blacks are hired into sales jobs than any other category (though the differences between sales and other white-collar jobs are just marginally significant), and fewer are hired into any white-collar job than into service or blue-collar jobs. In contrast, blacks are more frequently hired into sales or service positions than into other jobs in firms with predominantly black customers.

The tendency of blacks to obtain other white-collar jobs less frequently than nonblacks at establishments with predominantly white customers may reflect higher skill requirements in those jobs, despite our inclusion of numerous controls for these requirements. But the lower hiring of blacks into sales jobs, even relative to other white-collar positions, is unlikely to reflect higher skill requirements; more likely, it reflects a greater aversion on the part of white customers to dealing with blacks in a relative higher-status job category where customer contact is particularly frequent or intensive. Likewise, the finding that blacks are more likely to be hired into sales and especially service jobs than into blue-collar jobs in firms with predominantly black customers may indicate a similar preference for contact with their own racial group. ${ }^{32}$

Regarding differences in probabilities across customer categories within occupational groups, the probability of hiring blacks increases within each occupational group as the percentage of customers who are black rises. But, as was suggested by the differences in probabilities across occupations within customer categories, the effect of black customers on hiring is highest in sales occupations and smallest in blue-collar occupations.

Of course, it is possible that the results presented in part A of Table 4 are driven by unobserved factors on the demand side of the labor market, such as differences in skill needs or other sources of employer discrimination. It is also possible that they are driven by labor supply behavior rather than

\footnotetext{
${ }^{32}$ The extent to which sales jobs are higher in status will, of course, vary a great deal by the nature of the establishment and the product being sold.
} 
demand. Even though we control for the racial composition of job applicants in the second specification, the control is at the level of the firm, and may not capture racial differences in job application rates across jobs within firms. A logical response by blacks to discriminatory barriers at jobs in predominantly white firms (whether or not they involve customer contact) might be to apply heavily to jobs at predominantly black firms. Furthermore, whites may be more uncomfortable in jobs at predominantly black firms, which may affect their willingness to apply to these firms.

A comparison of the estimated effects on employment between jobs in the same occupation that do and do not involve contact with customers (in part B of Table 4) provides a way of dealing with unobserved heterogeneity across firms and jobs. If we assume that any effects of customer composition on hiring in noncontact jobs reflects only unobserved heterogeneity, then the difference between the estimated effects in contact and noncontact jobs within the same occupation yield an unbiased estimate of the effect of customer racial composition in that occupation. In other words, this would generate a difference-indifferences estimate, which would eliminate unobserved factors that are correlated with customer composition and that are fixed by occupation.

An additional advantage to this approach is that, given our categorical racial customer variable, we can generate estimates separately for firms with few and many black customers. If we think of the noncontact jobs in each occupation and customer category as representing the "base" level of black employment for that category in the absence of customer prejudice, then our difference-in-differences estimates can be interpreted as separate measures of discrimination among white and black customers. Negative differences (when subtracting effects on black employment in noncontact from contact jobs) where customers are predominantly white would be considered prejudice among whites, while positive differences where customers are predominantly black would reflect prejudice among blacks.

The estimated coefficients (along with standard errors and implied partials) appear in part B of Table 4, while the difference-in-differences estimates of implied partial derivatives evaluated at the sample 
means appear in part C. ${ }^{33}$ The results suggest that there is some prejudice among both black and nonblack customers. In firms with few black customers, there is little difference between the employment of blacks in contact and noncontact jobs within most occupations; but the differences between occupations, especially sales versus other categories, remain clear. Since, by definition, the sales jobs are all considered "contact" jobs, we compare them to other white-collar jobs in the noncontact category when computing the difference-in-difference estimates of partials; these estimates show clear evidence of discrimination among white customers against blacks in sales jobs, though little elsewhere.

In contrast, blacks are relatively more likely to be employed in jobs involving customer contact than in those that do not, even within occupation, in firms with many black customers, and this holds true within each occupational category. Thus, customer prejudice in favor of black employees seems quite widely prevalent in these firms. Results for firms with racially mixed customers vary across occupations, suggesting some discrimination against blacks in white-collar jobs and in favor of blacks in blue-collar or service jobs.

Of course, the difference-in-differences estimates are unbiased only to the extent that the unobserved factors that are correlated with race of customers are fixed within occupation and don't vary systematically between contact and noncontact jobs. ${ }^{34}$ On the other hand, these estimates also assume that there is no customer prejudice in the noncontact jobs. But workers hired into such jobs might still be visible to customers, even if they have no contact with them, and, if employees can be promoted over time from noncontact to contact jobs, customer preferences might influence hiring into entry-level, noncontact jobs as

\footnotetext{
${ }^{33}$ Given that the logit coefficients themselves are from nonlinear estimated functions, the differences are only meaningful with regard to implied partial derivatives.

${ }^{34}$ If, for instance, blacks feel relatively more comfortable applying for jobs without customer contact in firms with mostly white customers and with contact in firms with mostly black customers, even within occupation, then the difference-in-difference estimates would still contain some upward bias. But we know of no evidence that this is, in fact, the case.
} 
well. Thus, the difference in estimates between contact and noncontact jobs might actually generate lower bounds to the true customer effects.

\section{Net Effects on Labor Demand by Race}

What do these estimates imply about the overall demand for blacks and whites hired into newly filled jobs? In particular, do the apparent preferences of nonblack customers for nonblack employees and those of black customers for black employees offset each other overall, or do these preferences create net shifts in labor demand in favor of one group or the other? Evidence on this question is provided in Table 5.

Our estimates of net labor demand shifts for blacks are based on the implied partial derivatives of Table 4. Since these coefficients measure the effects of the racial composition of customers on the race of who gets hired at firms (controlling for other determinants of relative demand and supply), we can interpret them as measures of relative demand shifts across racial groups that are generated by customer preferences. To estimate marketwide shifts in relative demand, we compute weighted averages of the partial derivatives implied by difference-in-differences estimates of part B in Table 4 , where the weights are the percentages of all newly filled jobs in the relevant job categories. ${ }^{35}$

Three sets of difference-in-differences estimates are used. In the first two, we use differences between estimates for contact and noncontact jobs within customer racial category, which appear in part C of Table 4; the net demand shifts labeled "high" and "low" in Table 5 correspond to estimates from Columns 1 and 2, respectively, in part $\mathrm{C}$ of Table 4. The weights are the percentages of jobs in each racial category which are contact jobs in the relevant occupation.

\footnotetext{
${ }^{35}$ The interpretation of these weighted estimates as relative demand shifts is based on the assumptions that unobserved relative supply shifts as well as wage levels across jobs are uncorrelated with customer composition. We test the latter assumption below.
} 
TABLE 5

Net Effects of Customer Composition on Relative Demand for Blacks: Difference-in-Difference Estimates

\begin{tabular}{|c|c|c|c|c|c|c|c|c|c|c|c|c|}
\hline \multirow[b]{2}{*}{$\underline{\text { Percentage Customer Black }}$} & \multicolumn{4}{|c|}{$\begin{array}{c}\text { Differencing within Each Customer } \\
\text { Category: Low Estimate }\end{array}$} & \multicolumn{4}{|c|}{$\begin{array}{c}\text { Differencing within Each Customer } \\
\text { Category: High Estimate }\end{array}$} & \multicolumn{4}{|c|}{$\begin{array}{l}\text { Differencing across } \\
\text { Customer Categories }\end{array}$} \\
\hline & $.00-.25$ & $.26-.50$ & $.51-1.00$ & TOTAL & $.00-.25$ & $.26-.50$ & $.51-1.00$ & TOTAL & $.00-.25$ & $.26-.50$ & $.51-1.00$ & TOTAL \\
\hline \multicolumn{13}{|c|}{ Employment effects for each category } \\
\hline Percentage points & .002 & -.037 & .051 & - & -.023 & -.067 & .103 & - & -.055 & .030 & .109 & - \\
\hline Percent of black hires & .012 & -.219 & .302 & - & -.136 & -.396 & 609 & - & -.325 & .178 & .645 & - \\
\hline \multicolumn{13}{|c|}{ Effects weighted by size of category } \\
\hline Percentage points & .001 & -.005 & .002 & -.002 & -.014 & -.009 & .004 & -.019 & -.043 & .004 & .005 & -.034 \\
\hline Percent of black hires & .006 & -.029 & .012 & -.011 & -.100 & -.053 & .024 & -.129 & -.254 & .024 & .030 & -.201 \\
\hline
\end{tabular}

Note: Calculations based on differences across customer categories use differences between partial derivatives in each customer category and those of noncontact jobs in the middle customer category (i.e., .26-.50 black); only Column 2 estimates from Table 4 are used here. Calculations based on differences within each category use

differences between contact and noncontact jobs within each occupation and customer category; high estimates are from Column 1 and low estimates are from Column 2 in Table 4. 
However, as noted above, it is possible that differencing away the effects of customer race in noncontact jobs within customer categories might lead us to understate the true customer prejudice effect (if customer preferences have some effect on hiring into these jobs as well). We therefore provide a third set of estimates in which we compare jobs within occupations across racial customer categories. These estimates use noncontact jobs in the middle customer racial category (that is, where customers are 26-50 percent black) as the base group in which customer prejudice presumably plays no role in black employment. The estimated partial derivatives of black employment for these jobs are subtracted from those in comparable occupations, both for those with and without contact, in all of the relevant customer racial categories. ${ }^{36}$ These differences are then weighted by the percentages of jobs in each racial category that are accounted for by the relevant occupation-by-contact cell. Since the level of black employment in the base category in this exercise is quite high, we consider this set of estimates to be upper bounds only to the true net effect of customer discrimination on labor demand..$^{37}$

While computing any of the three sets of estimates, the weighting is initially done separately within each customer racial category. We therefore generate separate estimates of percentage-point demand shifts within each such category; dividing these by the mean of black employment among new hires (.169) generates labor demand shifts for or against blacks in percentage terms. Each of these within-category estimates can then be weighted by the percentages of new hires accounted for by each of the customer racial categories, which show that most jobs are found in predominantly white firms. ${ }^{38}$ Summing across these estimates then generates the total shifts in demand for black labor that can be attributed to customer preferences with each method.

\footnotetext{
${ }^{36}$ The difference-in-difference estimates that are used in this third set of calculations do not appear in part $\mathrm{C}$ of Table 4, but can be computed from the partials that appear in part B.

${ }^{37}$ The percentage of employees who are black in the "base" category here is 0.41 , which is quite high relative to the sample mean (0.17). We therefore use only the Column 2 estimates in this set of computations, which include the controls for race of applicants and survey respondent.

${ }^{38}$ These latter weights are $0.74,0.18$, and 0.08 , respectively.
} 
The results of Table 5 suggest that customer discrimination causes a net decline in overall labor demand facing blacks. However, the estimated magnitude of the decline varies considerably across the three calculation techniques. The estimates based on differences between contact and noncontact jobs within each racial category generate marketwide declines of labor demand for blacks in the range of from 1 to 13 percent. The estimate based on differences across racial customer categories (using occupations with high level of black employment as the "base") is considerably higher than this (roughly 20 percent).

The data consistently show that preferences among blacks tend to raise the demand for black labor by substantial amounts in those firms where black customers predominate; but these constitute such a small fraction of all firms that they raise overall demand for black labor by just 1-3 percent. In firms with few black customers, the estimated effects on demand for black labor tend to be negative but are very close to zero in the within-occupation, "low-estimate" case. Estimated effects in the middle racial customer category $(0.26-0.50)$ vary greatly with calculation technique.

\section{$\underline{\text { Wage Effects }}$}

Although reductions in net demand for black labor should reduce employment and/or wages for black employees overall, it is also possible that customer discrimination generates wage differences among blacks (or other groups), depending on where particular employees work.

Table 6 presents the results from estimating several versions of Equation (5). The dependent variable is the log of the starting hourly wage of the newly hired worker. Separate estimates appear for blacks and nonblacks; control variables now also include the age, education, and gender of the newly hired worker. The customer black variable appears in both continuous and categorical form.

The results of four specifications are reported. The first includes only the individual characteristics $\left(\mathrm{X}_{\mathrm{i}}\right)$ of workers, along with the MSA in which their establishment is located. The second through fourth specifications correspond to the three included in Tables 2 and 3, except that the $X_{\mathrm{i}}$ have been added in all cases. The different specifications allow for the potential effect of customer preferences 
TABLE 6

Effects of Black Customers on Log

(Starting Hourly Wages)

\begin{tabular}{|c|c|c|c|c|c|c|}
\hline \multirow[b]{3}{*}{ Controls } & \multirow{2}{*}{\multicolumn{2}{|c|}{ Continuous }} & \multicolumn{4}{|c|}{ Categorical } \\
\hline & & & \multicolumn{2}{|c|}{ Nonblacks } & \multicolumn{2}{|c|}{ Blacks } \\
\hline & Nonblacks & Blacks & $.26-.50$ & $.51-1.00$ & $.26-.50$ & $.51-1.00$ \\
\hline 1. Age, Education, Gender, MSA & $\begin{array}{l}-.164 \\
(.061)\end{array}$ & $\begin{array}{l}-.263 \\
(.062)\end{array}$ & $\begin{array}{l}-.067 \\
(.027)\end{array}$ & $\begin{array}{l}-.073 \\
(.042)\end{array}$ & $\begin{array}{l}-.127 \\
(.043)\end{array}$ & $\begin{array}{l}-.176 \\
(.040)\end{array}$ \\
\hline $\begin{array}{l}\text { 2. Firm Characteristics, Skill Needs, } \\
\text { and Occupation added }\end{array}$ & $\begin{array}{l}-.067 \\
(.055)\end{array}$ & $\begin{array}{l}-.158 \\
(.057)\end{array}$ & $\begin{array}{l}-.033 \\
(.024)\end{array}$ & $\begin{array}{l}-.023 \\
(.037)\end{array}$ & $\begin{array}{l}-.073 \\
(.038)\end{array}$ & $\begin{array}{l}-.094 \\
(.037)\end{array}$ \\
\hline 3. Location within MSA added & $\begin{array}{l}-.114 \\
(.056)\end{array}$ & $\begin{array}{l}-.196 \\
(.061)\end{array}$ & $\begin{array}{l}-.043 \\
(.024)\end{array}$ & $\begin{array}{l}-.050 \\
(.038)\end{array}$ & $\begin{array}{l}-.084 \\
(.039)\end{array}$ & $\begin{array}{l}-.112 \\
(.040)\end{array}$ \\
\hline $\begin{array}{l}\text { 4. Race of applicants and } \\
\text { respondent added }\end{array}$ & $\begin{array}{l}-.122 \\
(.061)\end{array}$ & $\begin{array}{l}-.101 \\
(.065)\end{array}$ & $\begin{array}{l}-.042 \\
(.025)\end{array}$ & $\begin{array}{l}-.052 \\
(.040)\end{array}$ & $\begin{array}{l}-.069 \\
(.039)\end{array}$ & $\begin{array}{l}-.059 \\
(.041)\end{array}$ \\
\hline
\end{tabular}

Note: Sample size is 442 for blacks and 1420 for non-blacks. 
on the firms in which workers are employed and the jobs which they hold, so that these characteristics are not fully controlled for in all cases. Controlling for other racial characteristics of firms (in the fourth specification) also enables us to determine whether or not customer composition per se affects employee wages, or only affects them indirectly by reallocating blacks into firms with predominantly black workers. ${ }^{39}$

The results of Table 6 suggest that wages are lower in areas where customers are predominantly black. This is true for black as well as nonblack employees, though the effects generally are somewhat larger for the former. Without controlling for any firm or job characteristics, blacks working in firms with no black customers earn about 26 percent more than those working in firms with only black customers. Controlling for job and firm characteristics as well as location within the MSA reduces this differential to 16-20 percent, while controlling for other racial characteristics reduces it to about 10 percent. Using the categorical rather than continuous customer variables shows reductions in wages that are somewhat smaller than these but they are still highly significant in most cases. ${ }^{40}$

Why might the wages of workers be reduced in firms with mostly black customers? The theoretical model of Section III suggests that this should be true only for nonblack employees in these establishments, who would be facing reduced demand for labor there. Clearly, the lower wages of black as well as nonblack employees at these establishments suggest that there must be other differences between firms that serve predominantly black and white customers. These might include lower capital-labor ratios, worse technology, greater labor market "crowding," and/or lower product market rents at the predominantly black firms. $^{41}$

\footnotetext{
${ }^{39} \mathrm{We}$ estimated some versions of the wage equation using the percentage of all employees at the establishment who are black rather than percentage of applicants, but the latter actually had a larger effect on wages than the former.

${ }^{40}$ These estimates do not allow for the possibility that the wages of blacks who are hired into firms with predominantly non-black customers might be reduced because they are reallocated from sales to other jobs. But given the relatively low wages of sales jobs in this sample (paying wages that are only marginally higher than those in laborer or service jobs in this category), this effect is likely to be very small.

${ }^{41}$ Lower capital-labor ratios or worse technology might be found in predominantly black establishments if the owners of these establishments are less wealthy than those of white establishments; crowding might occur
} 
Indeed, the fact that some negative effects of having mostly black customers remain even after controlling for other racial characteristics of the establishments suggests that product market differences play some role. Alternatively, the lower wages could simply be capturing lower unobserved skills among the workers who fill the jobs at these establishments. ${ }^{42}$

Given the relatively small number of firms that have predominantly black customers, and therefore the small effects of customer discrimination on raising employment there (as observed in Table 5), the low wages paid in these firms cannot contribute greatly to overall wage differentials between whites and blacks. ${ }^{43}$ But their effects on the relative wages of those blacks who actually obtain such employment appear to be quite substantial.

\section{Changes Over Time}

Earlier it was suggested that the importance of consumer discrimination may be growing over time as the result of the suburbanization and deindustralization of employment. Given that it is a single cross section, the MCSUI Employer Survey does not allow for a full investigation of this issue. However, other data, while not providing direct evidence, suggest that the importance of consumer discrimination might be growing over time.

Table 7 presents data for Atlanta and Detroit on the percentages of all employment and population found in residential areas with majority black populations in 1980 and 1990. Unique data are available on the Atlanta Region that indicate the number of private sector jobs by one-digit industry and year within

because of any kind of discrimination limiting employment of blacks in the predominantly white establishments (Bergmann 1971); and lower product market rents might reflect the lower relative incomes of black consumers.

${ }^{42}$ For instance, Hirsch and MacPherson (1994) suggest that the lower wages of blacks in predominantly black occupations largely reflects typically unobserved heterogeneity across workers and/or jobs.

${ }^{43} \mathrm{As}$ we note above, the estimated demand shifts in Table 5 suggest that only 1-3 percent of blacks are reallocated by customer discrimination towards these firms. Thus, the 10-20 percent lower wages of these establishments translate into just 0.1-0.6 percent lower wages of blacks overall because of customer discrimination. While negative wage effects can also be observed on the wages of those employed in the middle group of customers, the extent to which customer discrimination raises or lowers the employment of blacks in such firms is very uncertain from Table 5 . 
each of 45 planning areas called superdistricts. The Atlanta Region includes the city of Atlanta and the inner suburbs of the metropolitan area. ${ }^{44}$ In 1980, 7 of the 45 superdistricts in Atlanta had majority black populations; in 1990, the number of superdistricts with majority black populations included the 7 that existed in 1980 plus 4 more. For Detroit, similar data (but without the industry breakdown) are available for 120 political jurisdictions. The same four jurisdictions were majority black in both 1980 and 1990 .

Despite the increase in the number of majority black areas over time, the percentage of the Atlanta Region's jobs located in these areas declined from 27 percent in 1980 to 19 percent in 1990 . Hence, more of the region's jobs are now located in places where the racial composition of customers is likely to be predominately white. Moreover, the industry breakdown shows that the shift in jobs from majority black to majority white areas has been the greatest in those industries with the largest percentages of jobs involving consumer contact (such as financial services, utilities, and retail trade). Detroit also experienced a large decline in the fraction of jobs located in majority black areas, which fell from 31 percent in 1980 to 22 percent in 1990 .

While these results are only for two cities, they reflect the forces of job suburbanization and continuing high levels of residential segregation that characterize most urban areas in the United States. Of course, the black population is also suburbanizing, even more rapidly nationwide than that of whites (Farley and Frey 1993). But the data in Table 7 show that, at least in these two metropolitan areas, employment is declining in predominantly black areas more rapidly than is the population; thus, blacks

\footnotetext{
${ }^{44}$ In 1990 the Atlanta Region accounted for 0.83 and 0.92 of the metro area's people and jobs, respectively.
} 
TABLE 7

Percentage of Metro Area Jobs and Population in Majority Black Districts, 1980 and 1990

\begin{tabular}{|c|c|c|c|c|c|c|c|c|}
\hline & Total & Constr. & Mfg. & TCU & Wholesale Trade & Retail Trade & FIRE & Service \\
\hline \multicolumn{9}{|c|}{ Employment } \\
\hline \multicolumn{9}{|c|}{ A. Atlanta } \\
\hline 1980 & .27 & .21 & .31 & .41 & .26 & .23 & .26 & .27 \\
\hline 1990 & .19 & .19 & .29 & .32 & .21 & .17 & .15 & .20 \\
\hline \multicolumn{9}{|l|}{ B. Detroit } \\
\hline 1980 & .31 & - & - & - & - & - & - & - \\
\hline \multirow[t]{2}{*}{1990} & .22 & - & - & - & - & - & - & - \\
\hline & & \multicolumn{3}{|c|}{ Total } & Black & \multicolumn{2}{|r|}{ White } & \\
\hline \multicolumn{9}{|l|}{ Population } \\
\hline \multicolumn{9}{|l|}{ A. Atlanta } \\
\hline 1980 & & & .23 & & .73 & \multicolumn{2}{|r|}{.08} & \\
\hline 1990 & & & .17 & & .65 & \multicolumn{2}{|r|}{.06} & \\
\hline \multicolumn{9}{|l|}{ B. Detroit } \\
\hline 1980 & & & .32 & & .91 & \multicolumn{2}{|r|}{.14} & \\
\hline 1990 & & & .29 & & .88 & \multicolumn{2}{|r|}{.09} & \\
\hline
\end{tabular}

Note: These data are based on 45 superdistricts (or planning areas) in Atlanta and 120 political jurisdictions in Detroit. 
who continue to live in predominantly black areas will find fewer jobs available in establishments where they are relatively preferred by customers. ${ }^{45}$

Changes in the mix of industries and jobs over time may also contribute to a growing importance of customer preferences, as more jobs over time involve some contact with customers. To provide some evidence on this issue, data from the Public Use Microdata Samples (PUMS) for each of the four cities included in the MCSUI Employer Survey were used to cross-tabulate jobs by occupation and industry for 1980 and 1990. To estimate the number of jobs in a particular occupation/industry cell involving consumer contact, estimates were used from our employer survey data; we then computed weighted averages of these estimates, weighted by the fraction of all jobs in each year in each occupation-industry cell.

The results of this exercise are found in Table 8. Between 1980 and 1990 in all four cities the percentage of all jobs involving consumer contact increased by 3 to 7 percentage points, for a 6 percent increase overall. Of course, this exercise underestimates the true growth of jobs involving customer contact, since it allows for no growth in these jobs within the occupation-industry cells.

Thus, the effects of a given degree of customer discrimination may be growing over time, as more jobs involve customer contact and more jobs are located in predominantly white areas. Unless these effects are offset by rising residential integration or declining consumer tastes for discrimination over time, the results suggest that the negative effects of consumer discrimination on employment outcomes for blacks may be growing. ${ }^{46}$

\footnotetext{
${ }^{45}$ If the numbers of jobs and people were leaving the predominantly black areas at the same rate, we would merely be observing increasing residential and employment integration. The implication of rising integration for relative black employment and earnings in the presence of customer discrimination would be ambiguous, as we noted in Section III above. Metropolitanwide segregation indices suggest significant increases in racial integration in Atlanta but not Detroit over this decade, and somewhat modest increases nationwide (Farley and Frey 1993).

${ }^{46}$ It is possible that consumer tastes for discrimination will decline over time with growing integration, as greater exposure of racial groups to one another will diminish negative stereotypes and discomfort felt in the presence of the other group.
} 


\section{TABLE 8}

Estimated Percentage of Jobs Involving Direct Contact with Customers, 1980 and 1990

\begin{tabular}{lcc}
\hline & 1980 & 1990 \\
\hline Atlanta & .71 & .74 \\
Boston & .71 & .78 \\
Detroit & .65 & .69 \\
Los Angeles & .67 & .70 \\
\hline
\end{tabular}

Source: MCSUI Employers Survey, and 1980 and 1990 PUMS. 


\section{CONCLUSION}

We have shown that the racial composition of customers affects who gets hired into a firm. Specifically, the larger the fraction of minority customers in an establishment, the higher is the probability that workers from that minority group will be hired. In general, these effects are stronger for blacks than for Hispanics, and are therefore consistent with the evidence reported in previous studies.

The magnitudes of these effects are found to vary by occupational category and the degree of direct contact with customers on the job. We find that employers are most reluctant to hire blacks into sales jobs in establishments where most customers are not black; while employers with predominantly black customers prefer black employees in all jobs that involve direct contact.

These preferences of white and black customers are found to generate net shifts in labor demand away from blacks, though much uncertainty remains about the magnitudes of these shifts. The wages of blacks (and nonblacks) who work in firms with predominantly black customers are also reduced relative to those who do not. Finally, our data suggest that the importance of customer racial composition may be growing over time, as jobs move from majority black to majority white areas and as more involve direct customer contact.

In addition to the various caveats stated above regarding econometric issues, a few more of a conceptual nature deserve mention. First, our results reflect employers' perceptions of customer preferences, and these perceptions may not be accurate. Nevertheless, the exact source of the discrimination does not change its effects on relative labor market outcomes. Second, it is possible that there are real differences in the quality of services that customers receive between members of their own racial group and those of others, if the employees themselves have biases (or even differing levels of comfort). In this case, it may be inappropriate to label the labor market effects of customer preferences as "discrimination." 
Despite these caveats, our results suggest that the racial composition of customers has real effects on relative employment outcomes of whites and blacks. These effects, and how they are changing over time, certainly merit further study. 


\section{References}

Barron, John, Dan Black, and Mark Berger. 1993. "Do Workers Pay for On-the-Job Training.” Working Paper, University of Kentucky.

Becker, Gary S. 1971. The Economics of Discrimination. Chicago: The University of Chicago Press.

Bergmann, Barbara. 1971. "The Effect on White Incomes of Discrimination in Employment." Journal of Political Economy 79 (2): 294-313.

Bloch, Farrell. 1994. Antidiscrimination Law and Minority Employment. Chicago: University of Chicago Press.

Borjas, George, and Stephen Bronars. 1989. "Consumer Discrimination and Self-Employment." Journal of Political Economy 97 (June): 581-605.

Bound, John, and Richard Freeman. 1992. "What Went Wrong? The Erosion of Relative Earnings and Employment among Young Black Men in the 1980s." Quarterly Journal of Economics 107 (February): 201-32.

Cawley, John, Karen Conneely, James Heckman, and Edward Vytlacil. 1996. "Measuring the Effects of Cognitive Ability." Cambridge: National Bureau of Economic Research Working Paper no. 5645.

Cutler, David, and Edward Glaeser. 1995. “Are Ghettoes Good or Bad?” Cambridge: National Bureau of Economic Research Working Paper no. 5163.

Farley, Reynolds, and William Frey. 1993. "Latino, Asian and Black Segregation in Multi-Ethnic Areas: Findings from the 1990 Census.” Working Paper, Population Studies Center, University of Michigan.

Hirsch, Barry, and David MacPherson. 1994. "Wages, Racial Composition, and Quality Sorting in Labor Markets." Working Paper, Florida State University.

Holzer, Harry J. 1988. "Search Method Use by Unemployed Youth." Journal of Labor Economics 6 (January): 1-20.

Holzer, Harry J. 1991. "The Spatial Mismatch Hypothesis: What Has the Evidence Shown?" Urban Studies 28 (February): 105-22.

Holzer, Harry J. 1996a. "Employer Skill Needs and Labor Market Outcomes across Groups.” Madison: Institute for Research on Poverty Working Paper no. 1087-96

Holzer, Harry J. 1996b. What Employers Want: Job Prospects for Less-Educated Workers. New York: Russell Sage Foundation.

Holzer, Harry J., and Keith R. Ihlanfeldt. 1996. "Spatial Factors and the Employment of Blacks at the Firm Level." New England Economic Review (May/June): 65-82. 
Holzer, Harry J., Keith R. Ihlanfeldt, and David J. Sjoquist. 1994. "Work, Search and Travel Among White and Black Youth." Journal of Urban Economics, Fall.

Holzer, Harry J., Lawrence Katz, and Alan B. Krueger. 1991. "Job Queues and Wages.” Quarterly Journal of Economics 106 (August): 739-68.

Ihlanfeldt, Keith R. 1992. Job Accessibility and the Employment and School Enrollment of Teenagers. Kalamazoo, Mich.: W. E. Upjohn Institute for Employment Research.

Ihlanfeldt, Keith R. 1996. "Information on the Spatial Distribution of Job Opportunities within Metropolitan Areas." Journal of Urban Economics, forthcoming.

Ihlanfeldt, Keith R., and David J. Sjoquist. 1989. "The Impact of Job Decentralization on the Economic Welfare of Central City Blacks." Journal of Urban Economics.

Ihlanfeldt, Keith R., and Madelyn Young. 1994. "Intrametropolitan Variation in Wage Rates: The Case of Atlanta Fast-Food Restaurant Workers." The Review of Economics and Statistics (August): 425-33.

Kahn, Lawrence, and Peter Shearer. 1988. "Racial Differences in Professional Basketball Players' Compensation.” Journal of Labor Economics 6 (January): 40-61.

Kain, John. 1968. "Housing Segregation, Negro Employment and Metropolitan Decentralization.” Quarterly Journal of Economics 82 (2, May): 175-97.

Kain, John. 1992. "The Spatial Mismatch Hypothesis Three Decades Later." Housing Policy Debate, Fannie Mae, Volume 3, 1992.

Kenney, Genevieve, and Douglas Wissoker. 1994. "An Analysis of the Correlates of Discrimination Facing Young Hispanic Job-Seekers.” American Economic Review 84 (June): 674-83.

Mieszkowski, Peter, and Edwin Mills. 1993. "The Causes of Metropolitan Suburbanization.” Journal of Economic Perspectives (Summer): 135-48.

Nardinelli, Clark, and Curtis Simon. 1990. "Customer Racial Discrimination in the Market for Memorabilia: The Case of Baseball.” Quarterly Journal of Economics 105 (August): 575-95.

Neal, Derek, and William Johnson. 1996. "The Role of Pre-Market Factors in Black-White Wage Differences.” Journal of Political Economy (October): 869-95.

Neumark, David. 1996. "Sex Discrimination in Restaurant Hiring: An Audit Study." Quarterly Journal of Economics 111 (August): 915-41.

Offner, Paul, and Daniel Saks. 1971. “A Note on John Kain's 'Housing Segregation, Negro Employment and Metropolitan Decentralization."” Quarterly Journal of Economics 85 (1, February): 147-60.

Rodgers, William, and William Spriggs. 1996. "What Does the AFQT Really Measure? Race, Wages, Schooling and the AFQT Score." Mimeograph, College of William and Mary. 
Yinger, John. 1995. Closed Doors, Opportunities Lost. New York: Russell Sage Foundation. 